\title{
Palaeoenvironmental Background for the Early Paleolithic Occupation of the Volcanic Upland in the South Caucasus
}

\author{
Elena Belyaeva* \\ Department of Paleolithic, Institute for the History of Material Culture, Russia
}

Submission: October 22, 2020; Published: November 06, 2020

*Corresponding author: Elena Belyaeva, Paleolithic Department, Institute for the History of Material Culture, St-Petersburg, Russia

\begin{abstract}
Nowadays, it has been reliably established that the Early Paleolithic people producing both Oldowan and Early Acheulian industries initially occupied the volcanic upland of the South Caucasus not later than 1.9.1.85Myr (Olduvai subchron). This period was characterized by a much lower relief than at present and subtropic climate that favored a dispersal of the early humans. The volcanic activity created there fertile paleosols with grass covers feeding hunted herbivores as well as rocks suitable for manufacturing lithic artifacts. In the subsequent periods of the Early and the Middle Pleistocene the upland underwent uplifting that led to a gradual deterioration of climate and appearance of glacial-interglacial rhythms with an increasingly pronounced difference between warm and cold periods. However, the chronological ranges of the studied Acheulian sites suggest that the humans continued to occupy the region under both more and less favorable conditions. The early humans are believed to have spread most widely in the region in the Late Acheulian, supposedly during in the Holstein interglacial.
\end{abstract}

Keywords: South Caucasus; Volcanic upland; Early Paleolithic occupation; Palaeoenvironmental dynamics

\section{Introduction}

Favorable climate, landscape and natural resources are believed to be principal factors determining a dispersal of the Early Paleolithic humans in different regions of the Old World. The South Caucasus is well known to be sufficiently rich in the Early Paleolithic sites, which are located mostly in the volcanic upland (Figure 1) surrounded with the ranges of the Lesser Caucasus [1,2]. So, it is of special interest to consider the palaeoenvironmental conditions that made the region quite suitable and even attractive for settling the Early Paleolithic people. In the beginning it should be advisable to present a brief overview of the Early Paleolithic records reported from this territory. Then it will be possible to discuss all the data relevant to the topic under consideration.

\section{Early Paleolithic Sites in the Region under Review}

For today is it is known that in the volcanic upland of South Caucasus that there is a single site with a primitive Oldowan industry and about one hundred sites representing the Acheulian industries, which are distinguished for more complicated technologies and a diversified tool set including handaxes.

The majority Acheulian sites of the region are surface localities with many hundreds of flat and carefully fashioned handaxes accompanied with products of the Levallois technique (special cores and bladey or pointed blanks) made of obsidian or hyalodacite. Technological and morphological features of these artifacts are considered to be typical for the Late Acheulian period [1]. Stratified Late Acheulian assemblages were found only in two sites of the volcanic upland. In the Dashtadem 3 site (Figure 1) located in the northern part of the upland (Lori intermountain depression, Armenia) there is a thin layer yielding typical Late Acheulian handaxes as well as various small tools and products of the Levallois technique made of local gyalodacite [3]. Unfortunately, no dating material and paleontological remains preserved in this site. Similar Late Acheulian industry produced from obsidian was discovered in the sequence of buried paleosols exposed in the Nor Gekhi 1site located on the Kotaik volcanic plateau, Armenia (Figure 1). According to the $\mathrm{Ar}^{40 \mathrm{r}}-\mathrm{Ar}^{39}$ dates for ash samples extracted from the paleosols as well as covering basalts, the Late Acheulian site at Nor Gekhi 1site existed in the range of 350-325Kyr [4].

Since both mentioned sites have no paleontological remains, is will be necessary to involve into consideration the Acheulian site at Azykh Cave (800a.s.l.) situated on the Karabakh Ridge (Lesser Caucasus) fringing the volcanic upland in the south-east (Figure 1). In the Azykh sediment section there are two layers 
with partly similar Acheulian assemblages [5]. Both assemblages were attributed to the Late Acheulian but the older one shows some archaic features indicating rather the initial stage of this period [1]. The Acheulian layers of Azykh Cave yielded a number of faunal remains typical for the Singil complex placed into the range of $600-350 \mathrm{Kyr}$ [6]. Dating the upper Acheulian layer by the ESR and amino-acid racemization methods showed the age around $300 \mathrm{Kyr}[7]$.

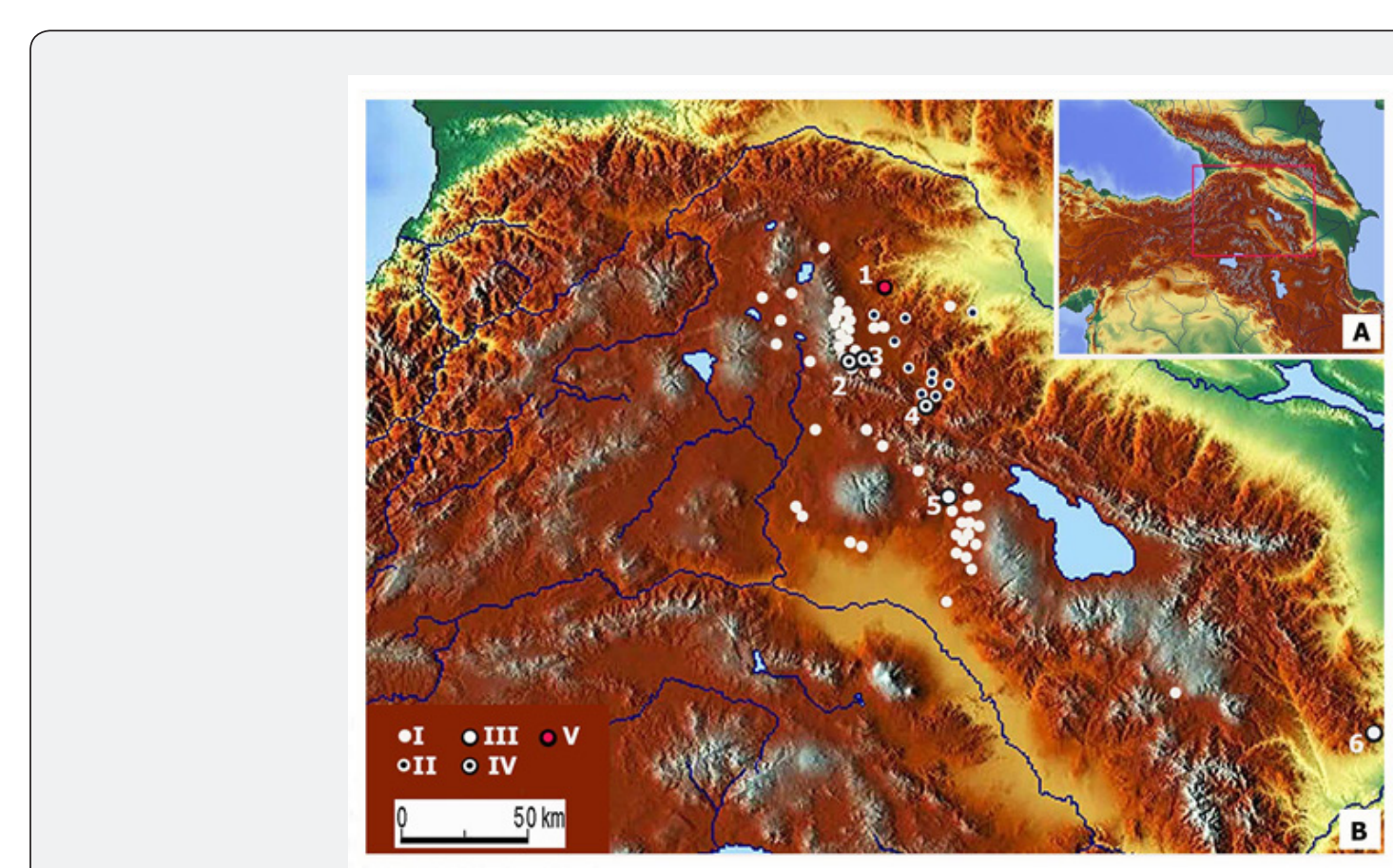

Figure 1: A. Map of the Caucasus and adjacent areas showing the location of the volcanic upland considered in the paper. B. Volcanic upland in the South Caucasus. I - Late Acheulian surface localities; II - Early-Middle Acheulian surface localities; III - Late Acheulian stratified sites; IV - Early and Middle Acheulian stratified sites; V - Oldowan site. Sites: 1-Dmanisi; 2-Karakhach quarry; 3 Muradovo; 4- Kurtan I; 5-Nor Gekhi 1; 6-Azykh Cave.

For a long time only, the Late Acheulian sites attributed on the whole to the second part of the Middle Pleistocene were known as in the volcanic upland as well as in other regions of the Caucasus [1]. However, at the end of the last century excavations of the medieval town Dmanisi in the northern part of the volcanic upland (Georgia) led to the discovery of the Early Pleistocene deposits containing typical Oldowan core-choppers and flakes made of local pebbles (Figure 2). Additionally, in the sediment sequence there were remains of pollen, fauna and even early men who produced the Oldowan industry $[8,9]$. The volcanogenic sediments of the site were subdivided into two major strata $\mathrm{A}$ and B. According to paleomagnetic records and the ${ }^{39} \mathrm{Ar}^{-40} \mathrm{Ar}$ dates [10] the lower stratum A occurred during the Olduvai subchron in the range of 1.85-1.78Kyr. The stratum B yielding most archaeological and anthropological finds was attributed to the period just after the Olduvai subchron, i.e. around 1.77-1.76Kyr [11,12].

In the beginning of this century new important discoveries happened in the Lori intermountain depression, Armenia (Figure 1) that is not far from the Dmanisi site. Three sites with the EarlyMiddle Pleistocene deposits and archaic Acheulian industries have been found in the foothills of volcanic Javakhetian Ridge
(Muradovo, Karakhach quarry) and folded Basum Ridge (Kurtan I quarry) $[13,14]$. Recently several localities with similar artifacts were discovered as well in the foothills of Somkheti Ridge (Figure 1) but their geological context remains to be seen. The key site was revealed in the Karakhach quarry (1800a.s.l.) where there is the sediment sequence $15-20 \mathrm{~m}$ thick subdivided into Beds I-III. No paleontological remains preserved in these volcanogenic deposits, but the presence of tephra provided an opportunity for absolute dating. Almost three thousand artifacts of the Early Acheulian aspect (crude handaxes, pics, choppers) were found in the entire lowermost Bed III $(\sim 8 \mathrm{~m})$ that consists of gravels, interbedded paleosols and ash lenses (Figure 3). The lower levels of the overlapping Bed II (tuff) also yielded a number of artifacts, which are partly similar to those of the Bed III $[13,14]$.

The Bed III with the main Early Acheulian industry shows normal magnetic polarity, whereas the overlying tuff $4-9 \mathrm{~m}$ thick has reverse polarity and five U-Pb dates in the range of 1.8$1.75 \mathrm{Myr}[15,16]$. Additionally, one of the ash lenses within the Unit III showed U-Pb age around 1.95Myr. However, based on somewhat younger K-Ar dates for basalt flows underlying clastic deposits in the vicinity of the Karakhach quarry, the lower age 
limit of the Unit III may be defined as $\sim 1.85 \mathrm{Myr}$. Given these deposits show normal magnetic polarity, the main Early Acheulian site at Karakhach evidently existed during the Olduvai subchron within the Matuyama epoch, in the range of 1.85-1.78Myr. The lower horizons of the Bed II (tuff), which also contain the Early Acheulian artifacts, deposited probably just after the Olduvai subchron, i.e. approximately 1.77-1.75Myr [16].

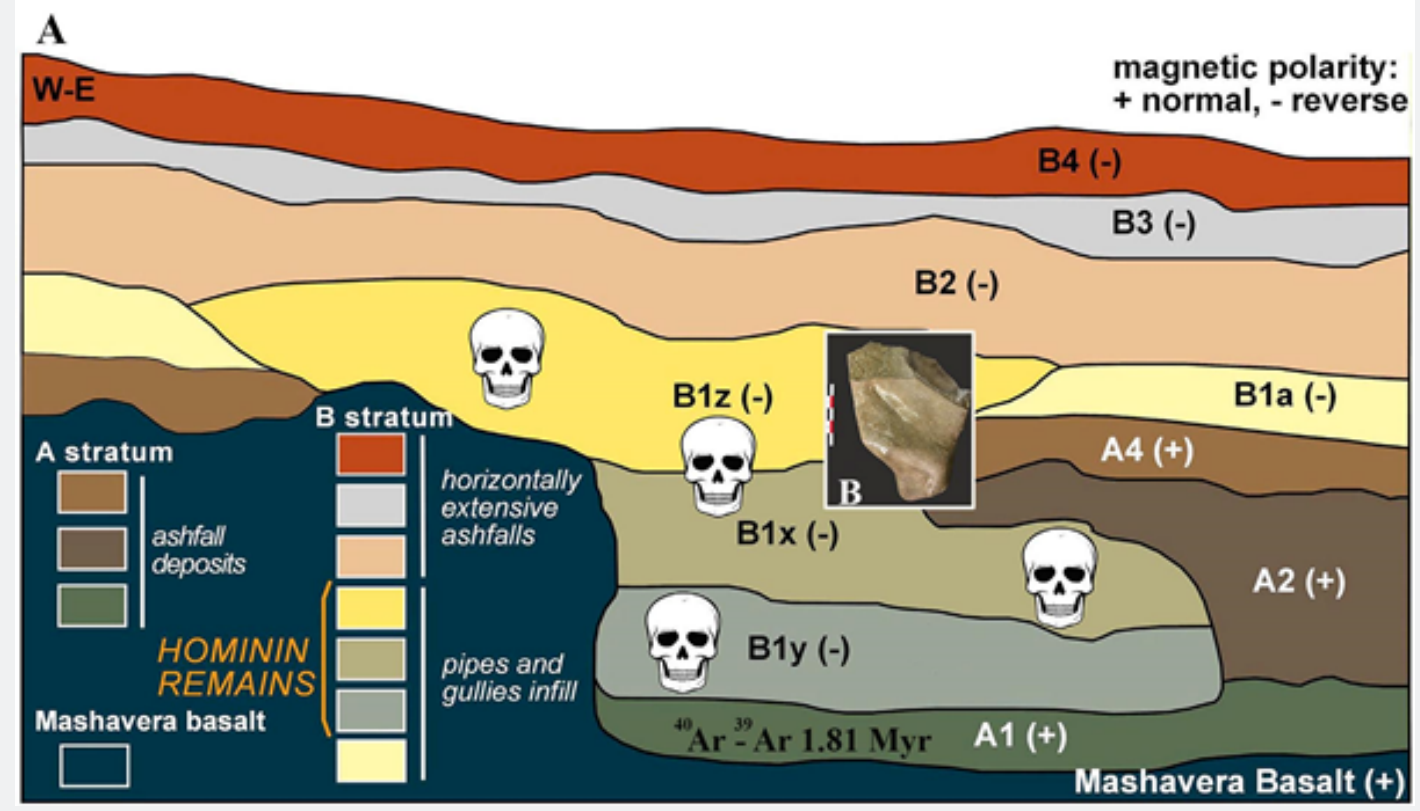

Figure 2: A. Sediment sequence of the Dmanisi site (after: Blain et al. [12]).

B. Chopper from the Bed B.

The nearby Muradovo site (Figure 1) is located at an elevation of 1549a.s.l. Under two horizons of a modern humus with a number of redeposited Late Acheulian pieces (layers 1-2) there is the clearly Pleistocene paleosol (layer 3) containing the Acheulian industry with certain archaic features (choppers, pics, absence of Levallois technique). The lower layers 4-9 consisting of mainly gravel and pebble deposits yielded even more archaic Acheulian artifacts (large crude handaxes, choppers, pics). Fauna and pollen were also absent there and, moreover, unlike at Karakhach, these layers were not covered with dateable tephra deposits. However, the layers 4-9 of Muradovo as well as artifacts in them look as those from the Bed III of Karakhach to such an extent that one can assume their close ages and define both industries as the local variant of the Early Acheulian $[13,14,16]$.

The Kurtan I quarry (1300a.s.l.) is located $30-35 \mathrm{~km}$ eastwards from both Karakhach and Muradovo (Figure 1). Three upper paleosols (layers 1-3) of the Kurtan I sediment sequence yielded the Acheulian industry (Figure 4A \& 4B) similar to that of the layer 3 of Muradovo. These paleosols were excavated in the point 2 where they are underlayed with pumice $(\mathrm{U}-\mathrm{Pb}$ date around 1.5Myr). The layers 1-2 of this paleosol sequence have normal values of paleomagnetic polarity (Brunhes epoch) and the lower layers 2a-3 ones has reverse values (Matuyama epoch). It means that the middle part of the sequence corresponds to the Matuyama-Brunhes transition $(\sim 800 \mathrm{Kyr})$. Additionally, one sample in the layer $2 \mathrm{a}$ showed normal polarity that reflects probably the Jaramillo subchron (0.99-1.07Myr). This suggests that the age of the layer 3 is around $1.0 \mathrm{Myr}$ or somewhat older. Based on these paleomagnetic readings and finding of two teeth of Stephanorhinus hundsheimensis existing in the range of 1.4-0.5Myr, the layers 1-3 of Kurtan I were attributed to a wide interval of 0.51.0Myr [16]. Lithic industry contained in these paleosols may be defined as the Middle Acheulian [13,14].

In the point 1 and 3 (Figure 4C \& 4D) between the upper paleosols and the pumice layer there are two additional stratigraphic units (layers 4-5): volcanic ash showing U-Pb age around $1.4 \mathrm{Myr}$ and below a layer of sandy loam with the signs of pedogenesis $\left({ }^{39} \mathrm{Ar} /{ }^{40} \mathrm{Ar}\right.$ date around $1.5 \mathrm{Myr}$ [15]. In the point 3 (Figure 4) under the pumice (layer 6) another thin paleosol (layer 7) lying just on the basalt flow has been revealed [17]. The K-Ar age of this basalt is around 2.0Myr [16]. Layers 4-6 show negative values of magnetic polarity but the lowest sample collected $1 \mathrm{~m}$ above visible bottom of the layer 6 (pumice) demonstrates normal polarity that probably corresponds to the upper limit of the Olduvai subchron. If so, the layer 7 of Kurtan I may be of the same age as the Early Acheulian sediment sequences of Karakhach and Muradovo. For today, however, two small diggings of this layer yielded only small flakes removed from small local pebbles (Oldowan industry?). 
Hence, there is more or less considerable evidence suggesting that the volcanic upland of the South Caucasus was populated by early humans at different stages of the Early Paleolithic [14]. It was also shown that until now very few stratified sites were found in the region and, moreover, only two sites, namely Dmanisi and Azykh, have yielded a variety of information on palaeoenvironmental conditions. However, this information may be supplemented with certain data from other sources that allow to starting a discussion on two principal issues:

a) main aspects of the Early-Middle Pleistocene environmental dynamics in the volcanic upland of the Southern Caucasus;

b) habitat values of the entire region and the areas occupied by the Early Paleolithic humans.

\section{Sources of Palaeoenvironmental Data and Research Methods}

The data which can be relevant for the topic come from studying both stratified Early Paleolithic sites and natural sediment sections corresponding to this period. As it has been aforementioned, the most valuable information on climate and landscape was reported by researchers studying the Early Paleolithic sites at Dmanisi $[5,11,12,18]$ and Azykh Cave [19]. These sediment sequences were forming within determined chronological intervals of the Early and Middle Pleistocene and yielded rich collections of pollen and faunal remains. Of special importance is plenty of pollen that allowed tracking climate and landscape changes in details. Additionally, the sets of fauna and pollen species may be involved to evaluate potential sources of food. Then, in the publication about these sites were also given data about such habitat values as the presence and availability of raw material. Very useful data on dynamics of natural conditions at the end of the Early Pleistocene were obtained thanks to the study of the natural section with paleo-lacustrine deposits near to the town of Shamb, Armenia [20].

Just after starting investigations of the very early Acheulian sites in the Lori depression, Armenia (Karakhach, Muradovo, Kurtan I) the observations concerning palaeoenvironmental conditions began to be made constantly during the excavation process. They were based on the visible characteristics of deposits (composition, facies change etc.) as well as the extracted artifacts (distribution, preservation etc.). Then, the integrated multidisciplinary studies were organized to collect the maximum amount of data on geochronology, geological setting and palaeoenvironmental dynamis in the excavated sites and in the relevant natural sediment sections.

A geochronological position of the sediment sequences was determined by using the K-Ar dating of volcanic rocks and the SIMS U-Pb dating of zircons extracted from tuffs $[15,16]$ as well as measuring of residual magnetic polarity of volcanic rocks and clastic sediments [16]. Two other interrelated research objectives were addressed through the following methods:

a. petrological and geochemical correlation of volcanic lavas and tuffs, underlain or covering clastic sediments and paleosoils,

b. detailed description of sedimentation units and sequences,

c. examination of faunal and plant remains if present,

d. correlation of different stratigraphic columns [16,21].

Particularly important data on paleoecological conditions were provided by additional research work in three directions that should be highlighted. The artifact-bearing pedosediments and paleosols have been analyzed in detail through a set of special methods (examination of chemical composition, micromorphological analysis, measuring of magnetic susceptibility etc.) $[17,22]$. The large numbers of phytoliths (petrified plant remains) found in the paleosols of Karakhach and Kurtan I has been studied too (A. Golyeva, pers. com.). Given there no data on fauna and pollen, namely these studies made it possible to make certain conclusions about climate and landscape changes. Finally, there was a comparative petrographic and geochemical analysis of Acheulian lithic artifacts as well as natural clasts from the cultural layers and rocks observed in the surrounding landscape (A. Nosova, pers. com). A purpose of the latter was to clarify what kinds of raw material were preferred by the Acheulian toolmakers and where these rocks might be procured.

Additionally, special studies were carried out to reconstruct the topography of the epoch when Early Paleolithic humans first arrived at the area. To find out how much the surface has elevated since the beginning of the Early Paleolithic measured values of incision of recent rivers into the reliably dated Early Pleistocene lava flows (K-Ar dates 2.65-1.7Myr) [16,23] have been taken as minimal magnitudes of uplifting. Various traces of local tectonic deformations and rearrangement of drainage systems were studied too [16].

\section{Results and Discussion}

For the present it is reliably established that the Early Paleolithic humans arrived into the volcanic upland of the South Caucasus not later than 1.85Myr (Dmanisi, Karakhach, probably Muradovo and the lowermost layer of Kurtan I). This period is characterized by continuous tectonic and volcanic activities that became highly intensive from the beginning of the Early Pleistocene. Basalt flows tens meters thick produced by numerous volcanic ridges and isolated domes covered almost the entire surface of intermountain depressions and dammed large and small water streams. Accordingly, most intermountain depressions such as Lori, Shirak, Upper Ahurian and others were flooded and turned to the lake basins [24]. Large river systems 
also underwent significant changes. For example, when lavas dammed the Akhurian River flowing to the south its upper current turned eastwards and entered into the Lori depression. This stream joined to the local Dzoraget River and formed a single river connecting the two neighboring intermountain depressions $[16,21]$.

In the northern part of the volcanic upland the areal eruptions of basalts occurred from 2.65 to $1.7 \mathrm{Myr}[16,23]$. In the south of the region the ages of the covering basalts are in the range of 2.5-2.25 Myr [25]. Besides the basalts other volcanic rocks such as various kinds of obsidians, dacites, andesites were also erupted by certain volcanos at the same time and somewhere even later. Hence, the volcanic manifestations preceded or were approximately synchronous with the initial appearance of early humans in this area. Despite of potential danger from intensive eruptions for the Early Paleolithic people, the volcanic activity brought them tangible benefits. The lava flows extending to the foot hills and intermountain plains created a small-scale topographic complexity (cliffs, rock shelters, natural traps, ravines, dammed lakes etc.) that was exclusively appropriate for inhabitance of early humans. Then, plenty of water sources as well as soils enriched by volcanic products generated fertile pastures providing an increase in the numbers of hunted herbivorous mammals. Immense amounts of volcanic rocks that were suitable for flaking and may be available over the landscape (outcrops, slope screes, channel gravels) were particular valuable for the Acheulian tool-makers $[13,16]$ who needed large-size raw material of good qualities for manufacturing various macro-tools (handaxes, picks, choppers etc.).

The basic information on palaeoenvironmental conditions in the region in the beginning of the Early Paleolithic was obtained thanks to excavations of the Dmanisi site (1015a.s.l.) located in the northern foothills of the Somkheti Ridge and around $15 \mathrm{~km}$ eastwards from the volcanic Javakhetian Ridge. To judge by characteristics of the exposed sediment section, the site was situated on a shore of a small dammed lake that appeared when basalt flows coming from Javakhetian Ridge blocked a local stream. The predominance of volcanic ash deposits over the entire stratigraphic column of the site (Figure $2 \mathrm{~A}$ ) suggests continuous or at least periodical ash falls [12], which, however, did not force people to avoid this place. The lower stratum A (1.85-1.78Myr, Olduvai subchron) yielded sufficiently scarce archeological finds that suggest rather periodical visits of the Oldowan people to the site than continuous occupation. The majority of finds including numerous lithic artifacts (Figure 2B) and rich anthropological remains came from the stratum $B(1.77-1.78 \mathrm{Myr})$ that reflects more intensive habitation in this place after the Olduvai subchron $[11,12]$.

At first, the data on pollen and fauna composition led to the conclusion that the Dmanisi site was continuously surrounded with a savanna-like landscape with isolated forest plots in the food plain and on some mountain slopes. The climate was characterized as a warmer and drier than at present. At the same time, the climate conditions were determined as somewhat more humid than those existing at that time in the in adjacent areas. The relatively increased humidity in the circumstances of Dmanisi was explained by the abundance of local water sources as well as the fact that at a distance of not more than $60 \mathrm{~km}$ northwestwards there was a bayside of the Paleo-Caspian Sea (Akchagyl Basin) [8].

Then a more detailed analysis of pollen and phytoliths from strata $A$ and $B$ allowed tracking some changes of climate conditions and landscapes. In the initial period of $1.85-1.78 \mathrm{Myr}$, when the Oldowan people began to visit Dmanisi, in the circumstances of the site there were many hygrophytic woody plants indicating a very warm (subtropic) and sufficiently humid climate. In the subsequent period (1.77-1.78Myr) characterized by a more active life of people in the site, the surrounding subtropic woody vegetation decreases and xerophytic grass plants became prevailing [18]. The analysis of reptiles and amphibians from the stratum B also shows that the Oldowan people occupied Dmanisi mainly in the conditions of warm and dry climate, similar to the present-day Mediterranean climate [12].

In the cultural layers of Dmanisi there were abundant remains of various animals including a number of herbivorous species inhabiting diverse biotopes (horse, giant and red dears, antelopes, gazelle, bison, rhinoceros, elephant, giraffe) [8]. At least some of these species may be hunted by the inhabitants of the site. Surely, they were also able to collect carcasses of large animals when they perished or were killed by carnivores (saber-toothed tiger, jaguar and hyena). Then, it is quite obvious that the sub-tropic woody vegetation around the site provided its inhabitants with numerous edible plants those are partly represented in the pollen spectra (chestnut, hazelnut, wingnut). The inhabitants of Dmanisi produced artifacts only from various pebbles (several kinds of silicified tuff, dolerite, andesite quartz, schist etc.) collected on the beaches of the nearby lake and local streams. Since the Oldowan people didn't make large and complicated tools they had no incentive for travelling toward the Javakhetian ridge to search for a better raw material.

The Early Acheulian sites in the Lori depression (Karakhach quarry, Muradovo) located at a distance around $30 \mathrm{~km}$ southwards from Dmanisi (Figure 1) were inhabited during the same period of the Early Pleistosene (Olduvai subchron). The Karakhach site (1800a.s.l.) is situated just near to a slope of the Javakhetian Ridge, which is covered with andesite lava. The Muradovo site ( $1649 \mathrm{~m}$ a.s.l.) is located around $3.5 \mathrm{~km}$ eastwards, near to a small isolated volcano. Judging by a configuration of lava flows around the site there might be a dammed lake. The cultural layers of the Karakhach and Muradovo sites consist of mainly multi-sized and badly sorted gravels deposited probably by slope washing, temporal springs and mud flows running from the Javakhetian Ridge $[13,14,16]$. At the same time, in the main Early Acheulian 
sediment sequence of Karakhach (Bed III) there are interbedded paleosols and thick ash lenses (Figure 3A) that suggest certain periods without intensive water erosion. The visible presence of some amount of ash in the almost all layers and the values of magnetic susceptibility for the latter indicate a more or less intensive volcanic activity during the Early Acheulian occupations of Karakhach. The Early Acheulian layers of Muradovo were eroded to a larger extent and the sequence contains only one layer of rewashed ash and no paleosols. Nevertheless, values of magnetic susceptibility for these sediments also indicate varying volcanic activity in the entire period of the Early Acheulian occupation [17]. Since the erupted products in both sites are represented mainly by ashes, at that time there were primarily ash falls. So, like the Dmanisi settlers, their Early Acheulian neighbors continued to inhabit or at least visit the Karakhach and Muradovo up to the end of the Olduvai subchron. Later volcanic activity in the region was increasing as evidenced by the tuff which overlaps the Early Acheulian layers at Karakhach. The bottom horizons of the tuff also contain the Acheulian artifacts, but the latter disappear in the overlying part of the unit. The tuff 4-9m thick consists of both ash and multi-sized pyroclasts that suggest sufficiently intensive and even catastrophic eruptions, which made it impossible for early humans to continue living in this area.

Since most Early Acheulian artifacts from Karakhach and
Muradovo are slightly rounded by water (Figure 3B), they hardly were found in situ. However, large quantities of lithic finds in all the Early Acheulian layers excavated in limited squares at Karakhach and Muradovo (around 3000 and 900 pieces, respectively) could not have been a result of casual transportation by small and changing streams. The most probable is that the artifacts were brought to these places or produced there by the Early Acheulian artisans. After being discarded the lithic artifacts were rounded and moved by periodical watercourses occurring hear in the periods of increasing humidity [14]. Finds of diatoms in the uppermost paleosol of this sequence suggests even the existance of a certain lake (A.Golyeva, pers. com.). One may propose that the Acheulian people hardly were the permanent inhabitants of theses repeatedly wetted localities. They rather visited these habitats rich in volcanic raw material from time to time for manufacturing lithic tools and other activities in certain convenient places. The Early Acheulian artifacts from Karakhach and Muradovo were made primarily of natural slab-lake clasts of rhyodacite and rhyolite. However, these rocks are rare in both ancient and modern gravels and not found in the nearby outcrops of the Javakhetian Ridge (A. Nosova, pers. com.). It suggests that the Early Acheulian tool-makers not only selected the most suitable raw material, but also were seeking and procuring this in some areas outside the surroundings of the sites.

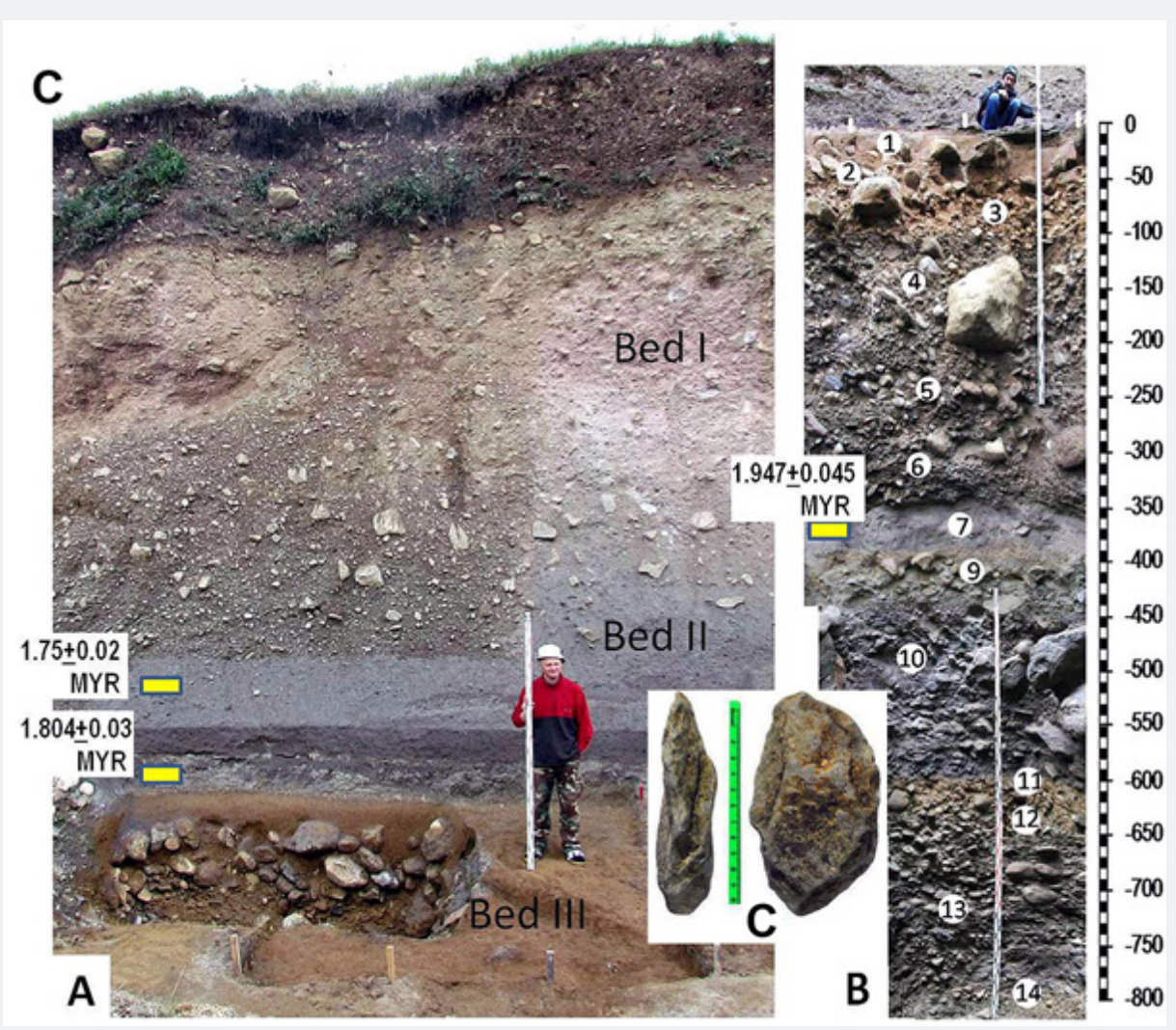

Figure 3: A. Sediment sequence in the Karakhach site, point 2.

B. Sediment section of the Bed III exposed in the point 2.

C. Handaxe, Bed III, layer 6. 
Despite the absence of fauna and pollen in both sites, some data on environmental dynamics in the period of the Early Acheulian occupation (1.85-1.77Myr) were obtained through a detailed analysis of reliably dated paleosols of the Unit III of Karakhach (Figure 3A) and the lowermost paleosol of Kurtan I (Figure 4C \& 4D) attributed to this period as was justified above. These paleosols were defined as the Vertic Cambisols and Colluvic Regosols Humic, which are indicators of a grassdominant paleovegetation and alternating wet and dry seasons over the year. Generally, the paleoenvironment of that time may be characterized as savanna-like landscapes with subtropical climate [17]. This conclusion was confirmed by the analysis of phytolites found in large quantities in the paleosols of Karakhach (A.Golyeva, pers. com.) Hence, the sites at Karkhach and Dmanisi existed not only at the same time but also in the similar environmental conditions. Since the sites are located only about $30 \mathrm{~km}$ away from each other, one may propose that the animals found in Dmanisi lived in the vicinity of Karakhach too.

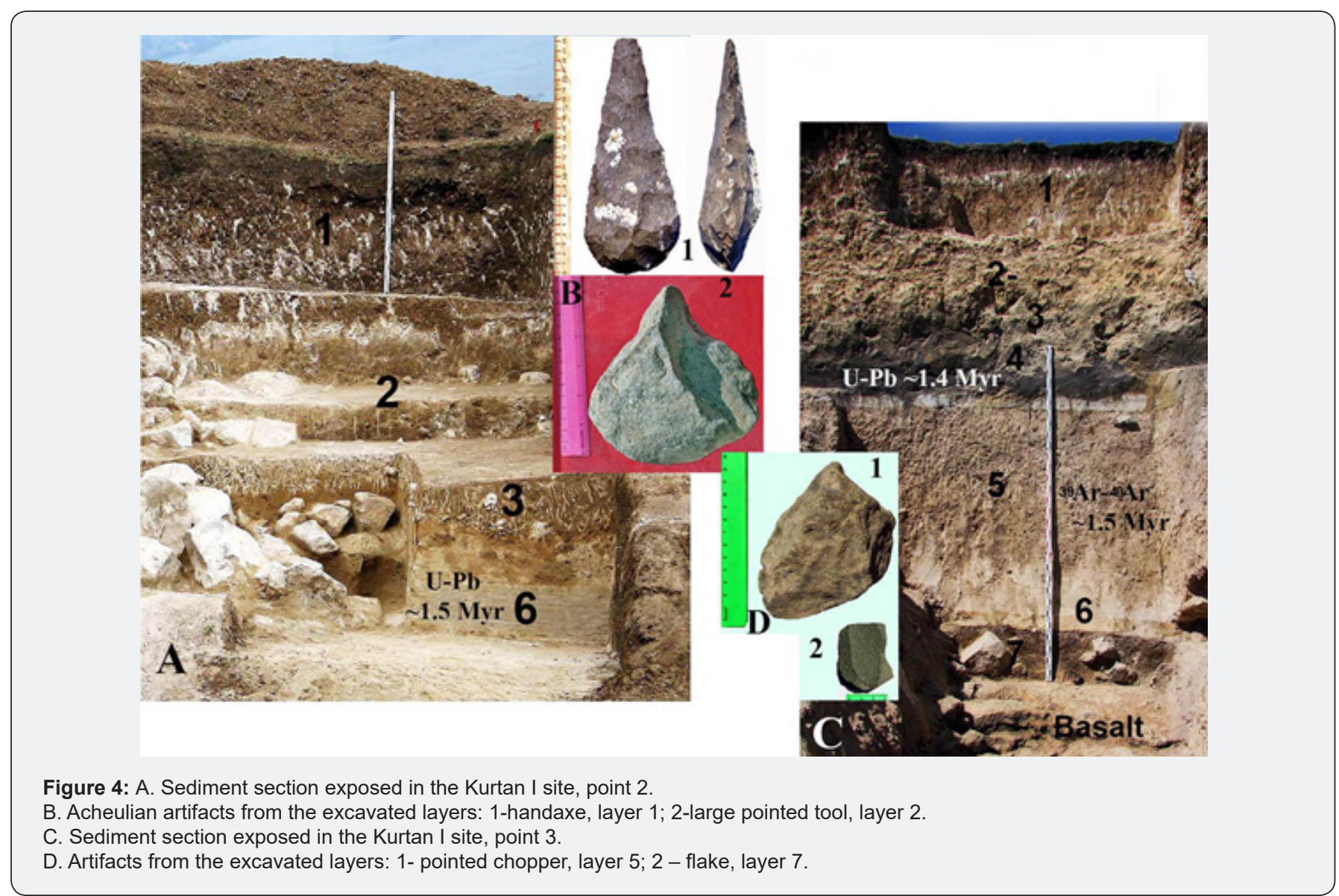

It should be noted, however, that the uppermost paleosol lying on the top of the Early Acheulian deposits at Karakhach has some special features suggesting that around $1.77 \mathrm{Myr}$ the climatic conditions in circumstances of the site remained subtropical, but became more humid. This inference does not coincide with the data from Dmanisi indicating increasing aridization just after the Oldovai ssubchron. The reason for this may be that the environmental conditions of this period were not absolutely uniform even in adjacent areas and sometimes varied under the influence of local geological factors [17]. Another explanation is that the uppermost paleosol of the Unit III of Karakhach may reflect a short humid period that was not revealed in the sediment sequence of Dmanisi.
In general, the environmental conditions existing in the considered period of the Early Pleistocene in the volcanic upland of the South Caucasus correspond to those reconstructed for this time for the Near East [26]. Since at present both climate and landscape of these regions are in many aspects different, their similarity in the period under consideration should be explained by special factors. As we are speaking about area with tectonic relief, it is obvious that the regional climate conditions and landscape were largely determined by the changing altitudes of the surface. Studies on tectonic deformations and surface uplifting carried out in the Lori depression and neighboring areas showed that in the beginning of the Early Paleolithic occupation, i.e. about $1,9-1.8 \mathrm{Myr}$ the intermountain plain was $500-1000 \mathrm{~m}$ lower and 
the ridges 1000-1500m lower than their modern altitudes (13001800 and 2500-3000, respectively) [16]. It means that at that period there were primarily midlands. It was also established that the uplifting rates were initially rather slow and began to increase after $500 \mathrm{Kyr}$. The same or similar uplifting occurred in the other areas of the volcanic upland $[21,26]$.

The proposed reconstruction of the relief existing in the volcanic upland of the South Caucasus in period of the initial human occupation is also relevant to the discussion on how early humans might come into the region. The matter is that the upland is the northern part of the so-called Armenian High Plateau located between the Caucasus and the Near East. Correspondingly, there is an opinion that this high mountain area was a physical barrier limiting dispersals of the Early Paleolithic humans to the Caucasus [27]. However, first, in any times people were able to overcome this upland thanks to long river valleys and intermountain depressions cutting the high relief in sub-meridional direction [28] and following the East Anatolian fault zone, which extends further the South Caucasus [29]. Then, though magnitudes of elevation in different parts of the Armenian High Plateau were hardly equal the data on the Early Pleistocene altitudes in the Lori sub-region may be partly extrapolated to the whole of this now mountainous area between the Caucasus and the Near East. If in the beginning of the Early Paleolithic in the Armenian High Plateau there were mostly midlands the ways through this area were quite convenient for the early humans.

Traces of the Early Paleolithic occupation of the region about $1.4-1.5 \mathrm{Myr}$ are represented by rare Acheulian artifacts found in the layer 5 of Kurtan I (Figure 4C \& 4D). The paleosol within the layer was defined as Luvisol that indicate the increase in humidity and somewhat colder climate [17]. The next stage of the Early Pleistocene was studied in the natural section of the diatomitic deposits of the Shamb paleo-lake in the south of Armenia. The ${ }^{40} \mathrm{Ar} /{ }^{39} \mathrm{Ar}$ dates and other characteristics including reverse polarity of the entire sediment sequence suggest that it probably ranges from 1.3 to $1.08 \mathrm{Myr}$ (MIS 41-39). The section does not contain lithic artifacts but should be mentioned as characterizing the period immediately preceding that which is reflected in the upper paleosols of Kurtan I. The analysis of both pollen and macroflora from the Shamb sequence first showed a clear alternation of glalcial and interglacial conditions. The glacial periods were relatively cold and dry, whereas the interglacials were warm with local humidity. At the same time, in general the climate became less warm and drier, gradually approaching the modern one [20].

The upper paleosol complex of the Kurtan I (layers 1-3) (Figure 4A) containing a level with the Matuyama-Brunhes transition $(\sim 0.8 \mathrm{Myr})$ has been attributed to the wide range of 1.0-0.5Myr [16]. However, the estimate of the upper age limit at $0.5 \mathrm{Myr}$ which was not determined by objective indicators may be somewhat rejuvenated. The matter is that the lithic industry from these layers shows many similarities to the earlier Acheulian complexes (Karahach, Muradovo) and has nothing in common with the Late Acheulian that begin to appear in this period in the Caucasus and adjacent regions [2]. The industry from the upper paleosols of Kurtan I (Figure 4B) may be defined rather as Middle Acheulian $[13,14]$. The raw material was gathered in the place and consist of local basalt, rhyolite removed from the nearby subvolcanic mount and rare pebbles of various rocks transported by paleo-stream. To judge by configuration of the layers and basalt bed the site was located probably on the shore of a drainage lake.

According to inferences from the paleosol analysis they were forming in the climate that was noticeably colder than in the Dmanisi and Karakhach period and gradually became more moderate [17]. Compared to Karakhach, the composition of phytoliths in these paleosols indicates the increase in the number of arboreal plants and, the appearance of coniferous species (A. Golyeva, pers. com.). Pollen was found in small numbers. The spectra are dominated by pollen of herbaceous vegetation with the leading role of Chenopodiaceae, Asteraceae, Poaceae, and Plumbaginaceae. Arboreal plants are represented by single pollen grains of Juniperus, Picea, Pinus, Betula, Quercus, Corylus, and Acer. This suggests prevailing meadows and woody patches on the mountain slopes. Scarce faunal remains from these deposits show that the inhabitants of the site had to meet but hardly hunted such large animals as Stephanorhinus hundsheimensis and Archidiskodon ex gr. meridionalis Nest. In the nearby natural section with synchronous sediments but without artifacts there were finds of bones attributed to a bison and a deer of the genus Praemegaceros [16].

Palaeoenvironmental data obtained during investigations of the Acheulian layers VI-V at Azykh Cave (800m a.s.l.) are believed to be relevant to the period around 600-350Kyr. This large cave is located on the slope of Karakakh Ridge (Figure 1) fringing the Tug depression (Figure 1). At present the height of the cave above the bottom of the local stream reaches $200 \mathrm{~m}$ but in the Acheulian time it was evidently much closer to the water course. The lower Acheulian layer VI (1m) is a loam enriched with weathered smallsized debris and a large amount of splittered animal bones. The layer $\mathrm{V}$ is much thicker $(3-5 \mathrm{~m})$ and consists of several multicolored loamy horizons with the more variable debris and the same bones $[5,19]$.

The pollen analysis [19] showed that there were several phases with alternating warm and cold conditions (Figure 5). In the initial period of the Acheulian occupation (most part of the lower Acheulian layer VI) the location of the cave corresponded to the border between the upper belt of mountain forest and subalpine light forest, i.e. the climate was sufficiently severe. Taking into account the proposed chronological limits, this period may be correlated with the cold conditions in the Middle Cromerian (OIS 16). Pollen from the top levels of the layer VI and the lower horizons of the layer $\mathrm{V}$ indicates a warm period with 
broad-leaved forest (second part of Cromerian Complex ?). The most part of the layer $\mathrm{V}$ contains pollen of birch, hopgrub and other plants suggesting a cold period that may be correlated with the Elster glacial. Finally, the uppermost horizon of the layer $\mathrm{V}$ was forming in the warm conditions when the cave was anew surrounded with mountain forest with broad-leaved plants (Holstein interglacial, OIS 11?). It should be noted, however, that the proposed correlation is very hypothetical because, first, in the sequence there are some stratigraphic breaks and, the second, the quantity of samples were too small to characterize all the level of the sediment section [1]. In the warmest periods the Acheulian inhabitants of the site were able to get plant food (chestnuts, acorns, walnuts etc.) directly in the forest near to cave. It is possible that in the colder periods some of these plants were also available if they preserved in the lowlands not too far from the site.

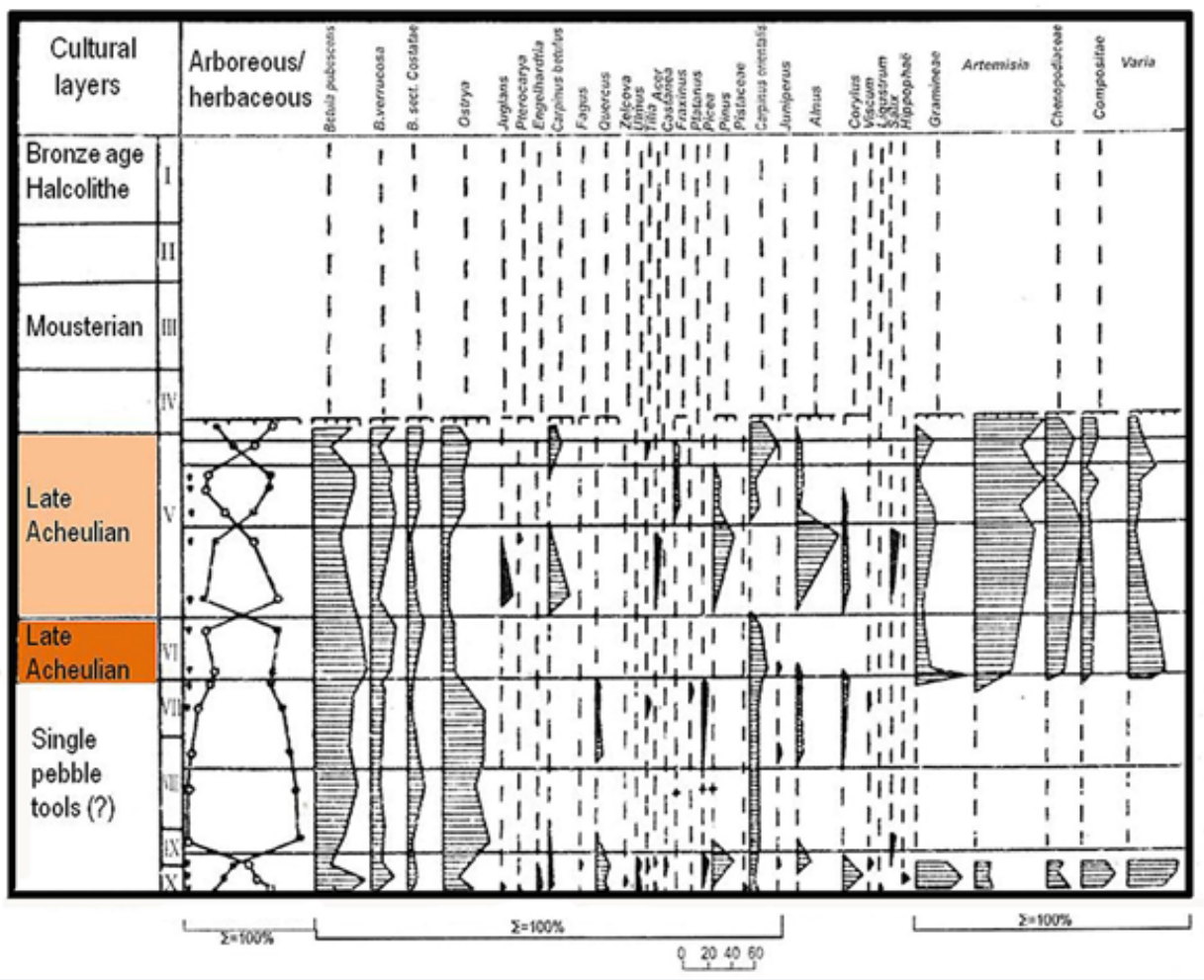

Figure 5: Azykh Cave. Pollen diagram (after: Velichko et al. [19]).

The two Acheulian layers of Azykh Cave yielded abundant remains of fauna including more than 40 species inhabiting different types of landscape: steppe areas, mountain and foothill forests, mountain meadows [5, 19]. More than ten species of herbivores such as giant and red dears, roe deer, gazelle, wild boar, bison, horse, saiga and some others might be a potential hunting prey. The predominant bones of red dear ( $>20$ individuals) were interpreted as evidence of specialized hunting for these animals [5]. At the same time, it is impossible to see the changes in fauna composition over the Acheulian period, because M.M Guseinov did not fix exactly the stratigraphic level at which each bone has been found [1]. It is noteworthy, that the Acheulian layers of Azykh Cave contained a considerable number of bones of cave bear and some other carnivores that hardly were a game of the early humans.
More likely that these dangerous animals visited or even occupied the cave at that time when the Acheulian people leaved it for some activities in other places.

Archaeological data led to the same conclusion. Even in the layer VI, which yielded almost two thousand various artifacts, they were collected in the area around $200 \mathrm{~m}^{2}$ so that their average density does not exceed 15 finds per cubic meter. The much thicker layer $\mathrm{V}$ yielded only 289 artifacts that concentrated mainly in different levels Based on this data M.M. Guseinov defined the Acheulian site at Azykh Cave as short-timed hunting camp, or bivouac [5]. At the same time, the artifact collections from both Acheulian layers contain complete sets of various products of knapping and tools purposed for different activities [30] that together with the abundance of splittered bones suggest not 
short visits of hunters but rather intermittent (seasonal?) periods of residence of small human groups. It is highly likely that they inhabited as well other natural shelters and surface localities, which were not discovered yet. These Acheulian tool-makers used different kinds of local raw material such as silicified limestone, sandstone and rarely felsite and basalt pebbles [5].

As it has been aforementioned, in the volcanic upland the Upper Acheulian period is represented by a large number of surface localities without geochronological context as well as a single stratified site of Nor Gekhi 1, which, however, yielded no paleontological remains. Absolute dating showed that this site was inhabited in the range of 350-325 Kyr [4] that roughly corresponds to the final stage of the Acheulian occupation of Azykh Cave distinguished by warm conditions (Holstein interglacial). Since the principal features of artifacts from the surface localities and those of the Nor Gekhi 1 site are similar enough, the Late Acheulian occupation of the entire volcanic upland may be assigned for the most to this warm period.

\section{Conclusion}

The volcanic upland of the South Caucasus was first occupied by the Early Paleolithic people not later than 1.85 -1.9Myr (Olduvai subchron). They were tool-makers of different lithic industries attributed as the Oldowan (Dmanisi, probably the lowermost paleosol at Kurtan I) and the Early Acheulian (Karakhach, the lower layers of Muradovo). In this period in the region and neighboring areas of the modern Armenian High Plateau there was mainly medium height mountain relief cut with tectonic intermountain depressions that appeared to be convenient natural corridors for moving the early people [2]. Like in the adjacent territories of the Near East, there were warm humid conditions and landscapes combining savanna-like and subtropic forest areas. Just after the Olduvai subchron the climate became drier and the savannalike landscape became predominant. Initially the early humans inhabited there in the conditions of periodical volcanic activity which was particularly intense in the previous period when lavas of basalt and then trahydacite and andesite covered intermountain plains and dummed local streams. The lava flows contributed to the formation of a complex small-scale topography (cliffs, rock shelters, natural traps, ravines, dammed lakes etc.) that favored the inhabitance of early humans. Additionally, the volcanic products led well to forming paleosols with a rich grass cover, i. e. this created vast pastures feeding a huge number of herbivores, which people could hunt. Of special importance was that some kinds of volcanic rocks proved to be exclusively suitable raw material for manufacturing large and technologically complicated Acheulian tools. Hence, during the Oldovai subchron of the Early Pleistocene the palaeoenvironmental conditions in the volcanic upland of the South Caucasus were quite favorable for inhabiting the Early Paleolithic people and resembled those existing in this period in their East African motherland [14,16].
In the subsequent periods of the Early Pleistocene and especially the Middle Pleistocene the upland surface underwent differentiated tectonic uplift, which has now reached 500-100 m for intermountain plains and $1000-1500 \mathrm{~m}$ for surrounding ridges [16]. In general, the climate gradually becomes more continental and cool but with alternating more and less favorable conditions in accordance with global glacial-interglacial rhythms. In glacial epochs the climate was colder and drier that led to development of steppe landscapes. In the interglacial periods it was warmer and wetter, which contributed to the spread of woody vegetation and the increase of water bodies. Of course, during all these periods there was also some interregional variability of landscape and climatic conditions depending on the type of relief and its height.

Evidence of the Early Paleolithic occupation of the region in the final part of the Early Pleistocene are represented by the Acheulian artifacts from the Kurtan I site, layers 5 and 3-2a (1.51.4 and around $1.0 \mathrm{Myr}$, respectively). This Middle Acheulian industry was also found in the upper Middle Pleistocene layers that suggests continuous occupation for a long period, despite the gradual deterioration of natural conditions and their fluctuations. The subsequent period of the Middle Pleistocene occupation of the region by Acheulian people is represented in the layers VI-V of Azyh Cave located on the Karabakh Ridge frihging the considered volcanic upland in the south-east [5]. Based on the indicative fauna composition these layers with the early Late Acheulian industry may be attributed to the range around of $600-350 \mathrm{Kyr}$ [6]. Both archaeological and palaeoenvironmental data from these layers suggest that the Late Acheulian tool makers periodically inhabited the cave during both interglacial and glacial conditions. The Nor Gekhi 1 site in the internal volcanic upland contains deposits the typical Late Acheulian industry existing around 350-325Kyr [4]. This age interval corresponds to the final warm stage of the human occupation at Azykh Cave that is probably the Holstein interglacial. Numerous surface localities of the volcanic upland with the Late Acheulian artifacts resembling those of Nor Gekhi 1 may be of the same age.

In the subsequent periods of the Middle Pleistocene the continuous uplifting of the upland under consideration resulted in a further deterioration of natural conditions and an increasingly unfavorable climate during glacial periods. It is indicative that the Middle Paleolithic sites in the region are represented by only three cave sites inside the canyons. Then, the Upper Paleolithic sites are practically absent there because in this period the palaeoenvironmental conditions in the region appeared to be too severe for human settlement [2].

\section{Acknowledgement}

The author is grateful to the former director of the ArmenianRussian archaeological expedition S. Aslanyan and its present director A. Petrosyan for their supporting in the Early Paleolithic research. Then many thanks are expressed to all colleagues 
who participated in field and laboratory works. The paper has been prepared within the framework of the FCR SAS program (state assignment №0184-2019-0001) on the topic "The oldest inhabitants of Russia and adjacent countries: ways and time of dispersals, evolution of culture and communities, adaptation to natural environments". The field and laboratory researches of the Karakhach, Muradovo and Kurtan I sites were conducted with funding of the Russian Foundation for Basic Researches (RFBR), grant № 18-00-00592.

\section{References}

1. Lioubine VP (2002) L'Acheuleen du Caucase. ERAUL 93, Liege.

2. Lyubin VP, Belyaeva EV (2006) Rannyaya prehistoria Caucasa (Early prehistory of the Caucasus). St-Peterburg (in Russian).

3. Kolpakov EM (2009) The Late Acheulian site of Dashtadem3 in Armenia. Paleoanthropology, pp. 3-31.

4. Gasparyan B, Adler D, Egeland Ch, Azatyan K (2014) Recently Discovered Lower Paleolithic Sites of Armenia. Stone age of Armenia. Monograph of the JSPS-Bilateral Joint Research Project. Center for Cultural Resource Studies, Kanazawa University, pp. 37-64.

5. Guseinov MM (2010) Drevniy paleolit Azerbaijana (The Lower Paleolithic of Azerbaijan). Baku (in Russian).

6. Baryshnikov GF (2002) Local biochronology of Middle and Late Pleistocene mammals from the Caucasus. Russian Journal of Theriology 1(1): 61-67

7. Fernandesz Jalvo Y, King T, Andrews P, Yepiskoposyan L, Moloney N, et al. (2010) The Azokh Cave complex: Middle Pleistocene to Holocene human occupation in the Caucasus. Human Evolution 58(1): 103-109.

8. Gabunia L, Vekua A, Lordkipanidze D (2000) The environmental contexts of early human occupation of Georgia (Transcaucasia) Journal of Human Evolution 38(6): 785-802.

9. Lumley H de, Nioradze M, Barsky D, Caushe D, Celiberti V, et al. (2005) Les industries lithiques preoldowayennes du debut du Pleistocene inferieur du site de Dmanissi en Georgie. L'Anthropologie 109(1): $1-182$.

10. Lumley H de, Lordkipanidze D, Feraud G, Garcia T, Perrenoud Ch, et al. (2002) Datation par la methode Ar/Ar de la couche de cendres volcaniques (couche VI) de Dmanissi (Georgie) qui a livre des restes d'hominides fossiles de 1, 81 Ma. C.R. Palevol 1: 181-189.

11. Ferring R, Oms O, Agustí J, Berna F, Nioradze M, et al. (2011) Earliest human occupations at Dmanisi (Georgian Caucasus) dated to 1.851.78 Ma. PNAS 108(26): 10432-10436.

12. Blain HA, Agustí J, Lordkipanidze D, Rook L, Delfino M (2014) Paleoclimatic and paleoenvironmental context of the Early Pleistocene hominins from Dmanisi (Georgia, Lesser Caucasus) inferred from the herpetofaunal assemblage. Quaternary Science Reviews 105: 136-150.

13. Belyaeva EV, Lyubin VP (2013) Achel'skie pamiatniki Severnoy Armenii (Acheulian localities of Northern Armenia). In: Molodin, V.I, Shun'kov, V. Basic problems of archaeology, anthropology and ethnography of Eurasia. To 70-anniversary of academician A. P. Dervyanko. Novosibirsk: 37-52 (in Russian).

14. Belyaeva EV, Lyubin VP, Trifonov VG (2019) Decouverte des sites Paleolithique inferieur au Nord de l'Armenie. L'Anthropologie 123(2): 257-275.

15. Presnyakov SL, Belyaeva EV, Lyubin VP, Radionov NV, Antonov AV, et al. (2012) Age of the earliest Paleolithic sites in the northern part of the Armenian Highland by SHRIMP-II U-Pb geochronology of zircons from volcanic ashes. Gondwana Research 21(4): 929-938.
16. Trifonov VG, Lyubin VP, Belyaeva EV, Lebedev VA, Trikhunkov Ya I, et al. (2016) Stratigraphic and tectonic settings of Early Paleolithic of NorthWest Armenia. Quaternary International 420: 178-198

17. Khokhlova OS, Sedov SN, Khokhlov AA, Belyaeva EV, Lyubin VP (2018) Signs of pedogenesis in the Early Pleistocene sediments containing tools of early hominins in the Northern Armenia and paleoclimatic reconstruction. Quaternary International 469: 68-84.

18. Messager E, Lordkipanidze D, Kvavadze E, Ferring CR, Voinchet P (2010) Palaeoenvironmental reconstruction of Dmanisi site (Georgia) based on palaeobotanical data. Quarternary International 223-224: 20-27.

19. Velichko AA, Antonova GV, Zelikson EM, Markova AK, Monoszon MH, et al. (1980) Paleogeographia stoyanki Azykh - drevneyshego poselenia pervobytnogo cheloveka na territorii SSSR (Paleogeographic data on the Azykh site, the oldest settlement of early man in the territory of SSSR). Izvestia Academii Nauk SSSR, seria geographicheskaya, № 3: 20-35 (in Russian).

20. Joannin S, Cornée JJ, Münch Ph, Fornari M, Vasiliev J, et al. (2010) Early Pleistocene climate cycles in continental deposits of the Lesser Caucasus of Armenia inferred from palynology, magnetostratigraphy, and $40 \mathrm{Ar} / 39 \mathrm{Ar}$ dating. Earth and Planetary Science Letters 291(1-4): 149-158.

21. Trifonov VG, Lyubin VP, Belyaeva EV, Lebedev VA, Trikhunkov Ya I, et al. (2014) Early Pleistocene of North-west Armenia: stratigraphy, archaeology and tectonics. The Quartenary of the Urals: global trends and Pan-European Quarternary records. International Conference INQUA-SEQS. Ekaterinburg, Russia, pp. 170-172.

22. Sedov SN, Khokhlova OS, Kuznetsova AM (2011) Polygenesis of volcanic paleosols in Armenia and Mexico: micromorphological records of climate 873 variations in the Quaternary Period. Eurasian Soil Science 44(7): 766-780.

23. Lebedev VA, Bubnov SN, Dudauri OZ, Vashakidze GT (2008) Geochronology of Pliocene volcanism in the Dzhavakheti Highland (the Lesser Caucasus). Part 2: Eastern part of the Dzhavakheti Highland. Regional geological correlation. Stratigraphy and Geological correlation 16(5): 553-574.

24. Sayadyan Yu V (2009) Noveyshaya geologicheskaya istoria Armenii (The Newest Geological History of Armenia). Ghitutyun, Yerevan (in Russian).

25. Chernyshev IV, Lebedev VA, Arakelyahts MM, Jrbashyan RT, Ghukasyan YG (2002) Geochronologia Aragatskogo vulkanicheskogo centra, Armenia: dannye K-Ar datirovania (Geochronology of the Aragats volcanic centre, Armenia: Evidence from K-Ar dating). Doklady Earth Sci 384: 393-398 (in Russian).

26. Bar Yosef O, Belmaker M (2011) Early and Middle Pleistocene Faunal and hominins dispersals through Southwestern Asia. Quaternary Science Reviews 30(11-12): 1318-1337.

27. Rolland N (2007) The early Pleistocene initial peopling of North Africa and Eurasia: major issues, Palaeolithic and fossil human evidence. Caucas i pervonachalnoe zaselenie chelovekom Ctarogo cveta, SaintPeterbourg, pp. 156-212.

28. Halatov V Yu (2003) Landshafty Armianskogo nagoria. Structura, classifikatcia, kartographirovanie (Landscapes of the Armenian high plateau. Structure, classification, mapping). Moscow (in Russian).

29. Trifonov VG, Karakhanyan AS (2004) Geodinavika i Istoria Civilizaciy (Geodynamics and the History of Civilization. Moscow (in Russian).

30. Shchelinsky VE (1994) Kamennye orudia truda ashel'skoy epokhi iz peschery Azykh (Asheulian lithic tools from Azykh Cave). Experimentalno-trasologicheskie issledovania $\mathrm{v}$ archaeologii. StPetesburg, pp. 3-41. 
Your next submission with Juniper Publishers will reach you the below assets

- Quality Editorial service

- Swift Peer Review

- Reprints availability

- E-prints Service

- Manuscript Podcast for convenient understanding

- Global attainment for your research

- Manuscript accessibility in different formats ( Pdf, E-pub, Full Text, Audio)

- Unceasing customer service

Track the below URL for one-step submission https://juniperpublishers.com/online-submission.php 